\title{
The International Association of Hydrogeologists (IAH): reflecting on 60 years of contributions to groundwater science and water management
}

\author{
Willi Struckmeier $^{1}$ - Ken Howard ${ }^{2}$ - John Chilton $^{3}$
}

Received: 21 March 2016 / Accepted: 26 May 2016 /Published online: 23 June 2016

(C) Springer-Verlag Berlin Heidelberg 2016

\begin{abstract}
The 60th anniversary of the founding of the International Association of Hydrogeologists (IAH) is an important milestone that allows pause for reflection on how the association has evolved over the years and the contributions it has made to groundwater science and water management. IAH was founded in 1956 at the 20th International Geological Congress and developed rapidly during the 1980s and 1990s in response to a growing global interest in groundwater mapping and in sound approaches to resource protection and sustainable aquifer management. Incorporated in 2000, IAH has now secured its position as the world's leading international association specialising in groundwater with over 4,100 members in 131 countries. Much credit for this success must go to members, past and present, whose individual efforts and collaboration with sister institutions are documented here. These members have shaped the association's goals and contributed selflessly to its scientific programmes, publications and educational and charitable activities. Looking ahead to the next 60 years, it is essential that IAH does not rest on past achievements but listens and adjusts to the needs of members while continuing to pursue its mission of furthering the understanding, wise use and protection of groundwater resources throughout the world.
\end{abstract}

W. Struckmeier is IAH past president (2008-2012); K. Howard is the current IAH president (2012-2016); J. Chilton is the IAH executive manager

John Chilton

jchilton@iah.org

1 Wandelbergsfeld 11, 31303 Burgdorf, Germany

2 Department of Physical and Environmental Sciences, University of Toronto Scarborough, Toronto, Ontario M1C 1A4, Canada

3 IAH, P O Box 4130, Goring on Thames, Reading RG 8 6BJ, UK
Keywords History of hydrogeology · Organisations · Groundwater management $\cdot$ Hydrogeology Journal

\section{Introduction}

Founded in 1956, the International Association of Hydrogeologists (IAH; https://iah.org/) enters its 60th year in 2016, an important milestone on a journey that officially began in Mexico City during the 20th International Geological Congress (IGC). Today, IAH has emerged as the world's leading international association specialising in groundwater, with over 4,100 members in 131 countries, more than 40 national chapters, 14 commissions and networks, 2 book series and an outstanding scientific journal—Hydrogeology Journal.

Anniversaries are a time for celebration; however, they also provide an important opportunity to reflect on past history, influential players, key events and the contributions that have been made to science and society. It is also an opportunity to look towards the future. This article begins by looking back at 60 years of successful development. It starts with a historical review of the association's formative years including the events and individuals that shaped its early beginnings, and continues with an examination of the 1980s and 1990s, two decades of continuing international growth and productivity. It then explores events surrounding the incorporation of IAH as a limited company in 2000 and the succeeding early years of the new millennium that lead to the present day. It is a story of success, but it is also a tale of hard work and selfless dedication by many association members, both nationally and internationally. The article ends with some thoughts on the future of the association and the challenges that may lie ahead. The 60th anniversary is a very important milestone for IAH, but the journey continues and much work remains to be done. 
Table 1 IAH councils and senior officers

\begin{tabular}{|c|c|c|c|}
\hline No. and dates of IAH councils & President & Secretary & Treasurer \\
\hline 1st: $1956-1960$ & $\begin{array}{l}\text { P Fourmarier/Belgium } \\
\text { F Penta/Italy (1960) }\end{array}$ & L Dubertret/France & G Castany/France \\
\hline 2nd: $1960-1964$ & $\begin{array}{l}\text { F Penta/Italy }(-1962) \\
\text { G Georgalas/Greece }\end{array}$ & L Dubertret/France & G Castany/France \\
\hline 3rd: 1964-1968 & H-J Martini/FR Germany & $\begin{array}{l}\text { L Dubertret/France } \\
\text { G Castany/France }\end{array}$ & W Fricke/FR Germany \\
\hline 4th: 1968-1972 & B Řezác/Czechoslovakia & $\begin{array}{l}\text { L Dubertret/France } \\
\text { G Castany/France }\end{array}$ & PE Groba/FR Germany \\
\hline 5th: 1972-1977 & S Buchan/United Kingdom & $\begin{array}{l}\text { L Dubertret/France } \\
\text { G Castany/France }\end{array}$ & PE Groba/FR Germany \\
\hline 6th: 1977-1980 & PE LaMoreaux/USA & $\begin{array}{l}\text { L Dubertret/France }(-1979) \\
\text { G Castany/France }\end{array}$ & PE Groba/FR Germany \\
\hline 7th: $1980-1984$ & G Castany/France & E Romijn/The Netherlands & PE Groba/FR Germany \\
\hline 8th: 1984-1989 & MR Llamas/Spain & E Romijn/The Netherlands & PE Groba/FR Germany \\
\hline 9th: 1989-1993 & E Romijn/The Netherlands & AC Skinner/UK & B Schwerdtfeger/FR Germany \\
\hline 10th: 1993-1996 & JE Moore/USA & AC Skinner/UK & $\begin{array}{l}\text { B Schwerdtfeger/Germany }(-1994) \\
\text { WF Struckmeier/Germany }(1994-1996)\end{array}$ \\
\hline 11th: $1996-2000$ & MR Knight/Australia & AC Skinner/UK & WF Struckmeier/Germany \\
\hline \multicolumn{4}{|c|}{ Incorporation of IAH in 2000 creates new Council and Executive structure including a new Science member } \\
\hline 12th: $2000-2004$ & E Custodio/Spain & AC Skinner/UK & $\begin{array}{l}\text { WF Struckmeier/Germany } \\
\text { P Bennett/USA (Science) }\end{array}$ \\
\hline 13th: $2004-2008$ & SSD Foster/UK & $\begin{array}{l}\text { M Veselic/Croatia (-2006) } \\
\text { WF Struckmeier/Germany }(2006-08)\end{array}$ & $\begin{array}{l}\text { J Sharp/USA } \\
\text { J Krasny/Czech Republic (Science) }\end{array}$ \\
\hline- & - & - & $\begin{array}{l}\text { VP Finance \& Membership and } \\
\text { VP Science \& Programme after } \\
\text { Rule change at Lisbon, } 2007\end{array}$ \\
\hline 14th: 2008-2012 & WF Struckmeier/Germany & S Puri/UK & $\begin{array}{l}\text { A Chambel/Portugal } \\
\text { KWF Howard/Canada }\end{array}$ \\
\hline 15th: $2012-2016$ & KWF Howard/Canada & S Puri/UK & $\begin{array}{l}\text { B Misstear/Ireland } \\
\text { A Chambel/Portugal }\end{array}$ \\
\hline
\end{tabular}

Updates can be found on the IAH website (IAH 2016); VP vice president

\section{The formative years: 1956-1979}

\section{Establishing the association}

As reported by Day (1992), the seeds of the association were sown in August 1948 during a hydrogeological excursion at the 18th International Geological Congress (IGC) in London, UK. These early post-war years were very difficult for scientists interested in fostering international co-operation, especially at the global scale. However, an exchange of ideas between Stevenson Buchan, a Scot working at the British Geological Survey (Gray and Mather 2004), and Georges Drouhin, the head of the hydraulic service in Algiers (Algeria), laid the foundations for an IAH organising committee ("Provisional Board") that convened for the first time at the following IGC meeting in Algiers in 1952. It was this committee, chaired by Drouhin and with Marcel Gautier as secretary, which prepared the way for the formal establishment of IAH on 8th September 1956 at the 20th IGC in Mexico City.
The original aims of the association, as set out in the statutes of 1957, were defined as "uniting all scientists interested in hydrogeology; holding scientific meetings and publication of worthwhile scientific results". The revised statutes of October 1975 slightly modify this as "to promote cooperation between geologists and specialists in all disciplines who are interested in hydrogeological problems". Thus, while hydrogeology was obviously at the core of IAH's activities, it was recognised from the beginning that collaboration with colleagues from other disciplines would enhance the association's ability to contribute to improving the scientific understanding of hydrogeology.

During the IGC, Paul Fourmarier of Belgium became IAH's first president (Table 1). Other members of IAH's first Council included Luis Blasquez (vice-president) from Mexico, Louis Dubertret (secretary general) and Gilbert Castany (treasurer), both from France. Total membership at this time was around 260, representing 35 countries. Most were European with French, Italian, Belgian and German 
hydrogeologists being the most numerous. In fact, more than three quarters of the initial membership was from France or the French colonies and protectorates (primarily Algeria), and it was only natural that Paris became the association's first administrative centre.

The first independent meeting of IAH, i.e. the very first IAH Congress, was held in June 1957 at the Sorbonne University in Paris and was attended by 62 members including 41 French scientists, 7 from Belgium, 4 from Germany, 3 from Switzerland and 1 delegate each from Cyprus, Czechoslovakia, Japan, The Netherlands, Turkey, USSR and Yugoslavia. The primary purpose of the meeting was to develop the objectives and statutes of the association and to decide upon operational and administrative matters such as fees and member services. One outcome was an agreement that the Council of IAH should include at least one representative for each of the official languages of the IGC, i.e. French, Italian, Spanish, German, English and Russian. As a consequence, Hans-Joachim Martini (German) and Grigori Kamensky (Russian) were elected to Council, as was Georges Drouhin.

\section{Activities in the early years of IAH}

In terms of member services, it was agreed to provide all members regularly with printed annual information bulletins (Bulletin d'Information) as well as monographs and proceedings of IAH meetings (Compte rendus and Memoires). Given that the principal language of IAH at the time was French, much of the material including IAH's information bulletins from 1958 (no. 1) to 1977 (no. 20) were published almost entirely in French with occasional articles in English. Lists of all printed publications provided to IAH members, together with the comprehensive history from which this article is drawn, can be found on the IAH website's History section (IAH 2016).

Also discussed at the first congress was the relationship between IAH and the International Commission on Groundwater (ICGW), a commission formed under the umbrella of the International Association of Hydrological Sciences (IAHS), established in 1922. It was concluded there was very little overlap or potential competition between IAHS and IAH, because the IAHS-ICGW originated from a purely physical and mathematical scientific background, whilst IAH mainly represented applied geologists focussed on the relationship between groundwater flow and geology. While this somewhat narrow perspective on the role and practice of hydrogeologists could be challenged today, the relationship between IAH and the IAHS-ICGW has remained strong over the years. IAH was fully functioning by the late 1950 s and published its first membership list in May 1959, providing the names and addresses of around 350 individual and 33 corporate members in 44 countries. France was best represented with 121 individual and 11 corporate members, followed by Algeria (40 individual +12 corporate), Italy (34 individual), Belgium (27 individual +4 corporate), FR Germany (18 individual +1 corporate), French West Africa (13 individual +3 corporate), USA (12 individual), and Spain (10 individual). The United Kingdom and Australia had just three individual members each. The annual membership fee for individuals was US\$3 (or 15 Swiss Francs or 17 French Francs). In 2016 terms, US\$3 would be about US\$24.

The founding phase of IAH was strongly supported by UNESCO, who in the early 1950s had proposed the creation of an International Union for Geological Sciences (IUGS). However, IUGS, to which IAH is affiliated, was only created in 1961, whilst IAH was recognized and fostered by the Water Sciences Division of UNESCO from its early days. Many projects of the IAH commissions and working groups have since received substantial support from UNESCO funds through its International Hydrological Programme (IHP). The field of hydrogeological mapping which emerged in the 1960s can be cited as a prominent example continuing until today with the World-wide Hydrogeological Mapping and Assessment Programme (WHYMAP). A report summarizing 50 years of close cooperation in hydrogeological mapping was published in 2014 (Gilbrich and Struckmeier 2014).

The main focus of IAH during its formative years was the advancement of science through the creation of commissions. The first of these was the Commission on Hydrogeological Maps, established in 1959 in Madrid (Table 2). Two more were added in 1968 - the Commission on Mineral and Thermal Waters, and the Commission for Karst Hydrogeology. Figure 1 is a photograph of some of the stalwarts of IAH's formative years on a Karst Commission field visit to the Dinaric region. By the early 1980s, the number had grown to include commissions for 'groundwater protection', 'volcanic terrain hydrogeology', and the 'hydrogeology of mining areas' (Table 2). These themes are not surprising; during the years of post war reconstruction and economic growth, which were also IAH's formative years, much of the emphasis in hydrogeology was on investigating the availability and suitability of groundwater to assure high-quality supplies for domestic, industrial and agricultural uses. Improved mapping of aquifers and the three-dimensional understanding of complex geological environments such as karstic and volcanic terrains was crucial to provide the technical basis for such development. The International Legend developed jointly by IAH and UNESCO in the 1960s still serves as a model for thematic hydrogeological maps throughout the world (Struckmeier and Margat 1995).

Advancing the science of hydrogeology was not, however, the new association's only activity. From the beginning, developing a strong professional network and community of like-minded colleagues was a key objective and the establishment of IAH national chapters was an essential part of this. 
Table 2 IAH commissions and working groups, 1959-2015

\begin{tabular}{lll}
\hline Name & $\begin{array}{l}\text { Year Chairs } \\
\text { started }\end{array}$ & Remarks \\
\hline
\end{tabular}

\begin{tabular}{|c|c|c|}
\hline $\begin{array}{l}\text { Commission for Hydrogeological } \\
\text { Maps (COHYM) }\end{array}$ & 1959 & $\begin{array}{l}\text { H Karrenberg, FR Germany to } 1982 . \\
\text { WF Struckmeier, FR Germany, 1982-2011 }\end{array}$ \\
\hline $\begin{array}{l}\text { Commission on the Geology of } \\
\text { Mineral and Thermal Waters } \\
\text { (CMTW) }\end{array}$ & 1968 & $\begin{array}{l}\text { K Fricke, FR Germany. H Schmassmann, } \\
\text { Switzerland. B W Zuurdeeg, The } \\
\text { Netherlands. J Dowgiallo, Poland. W } \\
\text { Balderer, Switzerland }\end{array}$ \\
\hline $\begin{array}{l}\text { Commission for the Hydrogeology } \\
\text { of Karst }\end{array}$ & 1968 & $\begin{array}{l}\text { A Burger, Switzerland. H Paloc, France. H } \\
\text { Hoetzl, FR Germany. N Goldscheider, } \\
\text { Germany }\end{array}$ \\
\hline $\begin{array}{l}\text { Commission on Groundwater } \\
\text { Protection }\end{array}$ & 1979 & J Vrba, Czechoslovakia \\
\hline Working Group on Remote Sensing & 1980 & M Deutsch, USA \\
\hline $\begin{array}{l}\text { Commission on the Hydrogeology } \\
\text { of Volcanic Terrains }\end{array}$ & $\begin{array}{l}\text { Early } \\
1980 \text { s }\end{array}$ & A Aureli, Italy \\
\hline
\end{tabular}

Phased out at Review of Commissions (ROC) in 2011

Renewed in 2011 as the Commission on Mineral and Thermal Waters, chaired by J LaMoreaux, USA, and A Porowski, Poland

Renewed in 2011 as the Commission on Karst Hydrogeology, chaired by $\mathrm{N}$ Goldscheider

Phased out at 2011 Review of Commissions

Uncertain when it ceased to be active

After almost a decade of work, the final manuscript of a monograph on volcanic rocks was stolen from Aurelio Aureli's car in Naples. There was no copy to replace it and the commission never recovered

Commission on the Hydrogeology of 1982 R Fernandez-Rubio, Spain Mining Areas

Commission on the Hydrogeology of 1983 V Cotecchia, Italy Coastal Areas

Commission on the Hydrogeology of 1986 Hazardous Waste

Burdon Commission on Hydrogeology in Developing Nations

Commission on Education and Training

Commission on Urban Groundwater

Commission on Groundwater and Aquatic Ecosystems

Commission on Hydrogeology in Arid Zones

Commission on Hydrogeology and Computers (CHCOM)

Commission on Hydrogeology of Hard Rocks (started as a working group)

Commission on Transboundary Aquifer Resource Management (TARM)

Commission on Managed Aquifer Recharge (MAR) (Working Group on Artificial Recharge from 1996)

Commission on Groundwater and Climate Change

Commission on Groundwater Dependent Ecosystems

Commission on Aquifer Dynamics and Coastal Zone Management

Early Career Hydrogeologists Network
1987

1993

1993

1993

1993

1996

1996

1999

2000

2002

2003

2003

2009
P LaMoreaux, USA. J Vrba, Czechoslovakia

S Foster, UK, to 1997. David Ball, Ireland, to 2005. Then A McDonald, UK

JE Moore, USA. R Aldwell, Ireland

D Lerner, UK, to 1997. Then K Howard, Canada R Llamas, Spain

J Lloyd, UK

GD Moore, USA

J Krâsny, Czech Republic

S Puri, UK

I Johnson, USA. P Dillon, Australia

A Issar, Israel, until 2008. Then R Taylor, UK C Colvin, South Africa

G Barrocu, Italy

J Flugge, Germany. V Re, Italy
A commission that started with great enthusiasm. Later the International Mine Water Association was created with Fernandez-Rubio as first president

Ceased activity in the late 1980 s and terminated by Council in 1990, revived by G Baroccu, Italy (see the following)

Active for a few years

Renewed as a network at the 2011 ROC and now renamed Burdon Groundwater Network for International Development

Terminated by decision of Council in 2005

Renewed in 2011 as the Urban Groundwater Network

Not active by 1999. Revived in 2003 as Groundwater Dependent Ecosystems by C Colvin (see the following)

Active very briefly

Active for 2-3 years

Renewed in 2012 as the Network on Fractured Rock Hydrogeology, chaired by U Troeger, Germany

Phased out at the ROC in 2011 and re-established in 2015 with same chair

Renewed in 2011 with the same name and chair

Renewed at the 2011 ROC with the same name and chair

Re-established at 2011 ROC as Network on Groundwater and Ecosystems, chaired by $\mathrm{J}$ Gurrieri and M Wireman, USA

Re-established at 2011 ROC as Network for Coastal Aquifer Dynamics and Coastal Zone Management (CAD-CZM), chaired by G Barrocu, Italy

New network set up in 2009 and formalized at 2011 ROC 
Table 2 (continued)

\begin{tabular}{|c|c|c|c|}
\hline Name & $\begin{array}{l}\text { Year } \\
\text { started }\end{array}$ & Chairs & Remarks \\
\hline $\begin{array}{l}\text { Commission on Groundwater } \\
\text { Outreach }\end{array}$ & 2011 & A Stone, USA & New commission established at 2011 ROC \\
\hline $\begin{array}{l}\text { Commission on Regional } \\
\text { Groundwater Flow }\end{array}$ & 2011 & J Mádl-Szőnyi, Hungary & New commission established at 2011 ROC \\
\hline Working Group on Education & 2014 & B Misstear, Ireland & $\begin{array}{l}\text { Responds to IAH Forward Look objectives; unrelated } \\
\text { to previous commission }\end{array}$ \\
\hline $\begin{array}{l}\text { Commission on Groundwater and } \\
\text { Energy }\end{array}$ & 2015 & G Ferguson, Canada & - \\
\hline
\end{tabular}

Updates can be found on the IAH website (IAH 2016)

The first national group was set up by Paul Fourmarier in Belgium in 1958 and chapters in France, Spain, Italy, Czechoslovakia, Germany and Yugoslavia followed in the early 1960s. Technical meetings and field visits organised by the chapters in the national language enabled the association to reach, support and encourage many more hydrogeologists and, like the commissions, chapters quickly became an important component of the overall benefits of IAH membership.

The printing and distribution of publications had been an important objective for IAH presidents and councils since the very beginning of the association. Moreover, publication of scientific achievements in which IAH was involved needed to be brought to the professional world both inside and outside the association. Provision of publications was seen as an important benefit of membership but the increasing printing and global distribution costs were becoming a growing concern. The early technical volumes, which consisted of the proceedings of IAH congresses (usually published locally by the organisers on behalf of IAH), and other occasional publications, were distributed free of charge to IAH members (Table 3). The early IAH congresses featured important hydrogeological themes of the time, including the groundwater balance and reserves of aquifers, methods for applied groundwater studies, applied hydrogeology and civil engineering, hydrogeological maps and karstic hydrogeology. This general outline was followed in each congress and occasionally supplemented by other, frequently regional, themes such as volcanic rocks at the Rome congress in 1961. The French titles of the early volumes in the table reflect the dominant role in IAH played by French-speaking hydrogeologists at that time. After 1990, congress proceedings were only distributed to participants.

\section{Expansion and challenges in the 1970s}

The 1970s proved to be a critical period for the fledgling organisation, a time of increasing membership and a widening of its geographical basis, shown by the establishment of new chapters in Ireland, the USA and Canada. Together with growth in scientific activities and the development of closer ties with other organisations, this started to put a strain on resources and tested the character of some of its leading figures. Increased expectations of the membership were beginning to expand the workload for Council, putting particular stress on the IAH Secretariat and the Treasurer. Towards the end of his 4-year term as president (1972-1976), Stevenson
Fig. 11973 IAH Karst

Commission field visit, Kotor,

Montenegro (photo courtesy of Petar Milanovic)

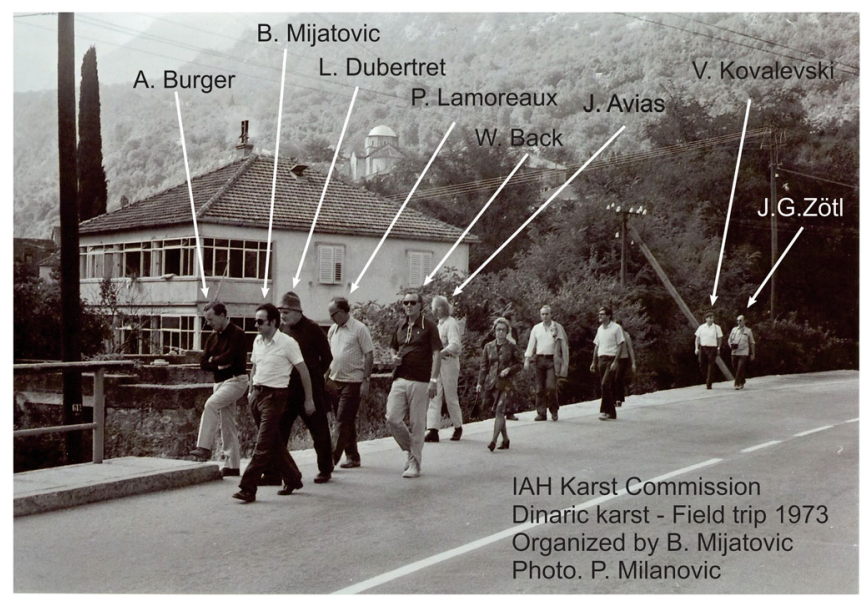


Table 3 Proceedings (memoirs) of IAH congresses 1957-1990

\begin{tabular}{|c|c|c|}
\hline Number & Year of Publication & Theme and number of IAH Congress and year \\
\hline Tome 1 & 1959 & Réunion de Paris, 1st IAH Congress, 1957 \\
\hline Tome 2 & 1959 & Réunion de Liège, 2nd Congress, 1958 \\
\hline Tome 3 & 1961 & Réunion de Madrid, 3rd Congress, 1959 \\
\hline Tome 4 & 1962 & Réunion de Rome, 4th Congress, 1961 \\
\hline Tome 5 & 1964 & Réunion d' Athènes, 5th Congress, 1962 \\
\hline Tome 6 & 1966 & Réunion de Belgrade, 6th Congress, 1963 \\
\hline Tome/vol 7 & 1967 & Réunion de Hannover, 7th Congress, 1965 \\
\hline Tome 8 & 1967 & Réunion d'Istanbul, 8th Congress, 1967 \\
\hline- & 1970 & International Legend for hydrogeological maps (IAH, IAHS and UNESCO) \\
\hline Tome/vol 9 & 1972 & Tokyo, 9th Congress, 1971 \\
\hline Tome 10 & 1974 & Congrès de Montpellier, France (10th), 1974 \\
\hline- & 1975 & Hydrogeology of karstic terrains (IAH and IUGS) \\
\hline Volume 11 & 1975 & Congress of Porto Alegre, Brazil, (11th), 1975 \\
\hline Volume 11 & 1978 & Hydrogeology of great sedimentary basins, 14th Congress, Budapest, 1976 \\
\hline Volume 12 & 1977 & Proceedings of the 12th Congress, Karst Hydrogeology, Huntsville, USA, 1975 \\
\hline Volume13 & 1977 & $\begin{array}{l}\text { Optimal development and management of groundwater, 13th Congress, } \\
\text { Birmingham, UK, } 1977\end{array}$ \\
\hline Volume 14 & 1978 & Budapest conference \\
\hline Volume 15 & 1979 & Methods for evaluation of groundwater resources, 15th Congress, Vilnius, 1979 \\
\hline Volume 16 & 1982 & Impact of agricultural activities on groundwater, 16th Congress, Prague, 1982 \\
\hline Volume 17 & 1985 & Hydrogeology of rocks of low permeability, 17th Congress, Tucson, 1985 \\
\hline Volume 18 & 1985 & Hydrogeology in the service of man, 18th Congress, Cambridge, 1985 \\
\hline Volume 19 & 1987 & $\begin{array}{l}\text { Integrated land use planning and groundwater protection management in rural areas, } \\
\text { 19th Congress, Karlovy Vary, Czechoslovakia, } 1986\end{array}$ \\
\hline Volume 20 & 1987 & Rome, 20th Congress, 1987 \\
\hline Volume 21 & 1989 & Karst hydrogeology and karst environment protection, 21st Congress, Guilin, 1988 \\
\hline Volume 22 & 1990 & Water resources in mountainous regions, 22nd Congress, Lausanne, 1990 \\
\hline
\end{tabular}

Buchan remarked that despite the very favourable signs of growth, "running the association is now becoming quite a heavy task". The increasing burden of work on the Secretariat and Treasurer became a recurring concern in subsequent decades as the association grew.

As evidence of the mounting pressure, information bulletins began to appear with less frequency during the 1970s and concerted efforts were made to limit the association's rapidly expanding scientific programme "to ensure that the activities of IAH are kept within its financial and other capabilities" (Information Bulletin Nos. 17-19). The association also struggled to collect annual fees from members in countries that had restrictions on obtaining and transmitting foreign currency and this had a constraining effect on the expansion of membership and consequently on the finances of the association. In the late-1970s, only 800 of the 1200 members were regularly paying fees which by that time had risen to $30 \mathrm{DM}$ (17 \$ US or $50 \mathrm{FF}$ ). In 2016 terms, US\$17 would be about US\$55.

Despite these difficulties, IAH continued to push forward due to the diligent work and strong commitment of its elected officers. In 1977, Phil LaMoreaux of the USA was voted president of a new Council (Table 1) at a well-attended congress in Birmingham, UK, and during the event the association celebrated its very first general assembly outside the confines of the IGC, a true sign of its maturity and growing independence. Unfortunately, when IAH seemed to be progressing well and ably coping with some of its inevitable "growing pains", tragedy struck. On an extended field trip following the 1979 congress held in Vilnius, the Lithuanian Republic of the USSR, IAH Secretary General Louis Dubertret sadly died.

Louis Dubertret, founding member and first secretary general of the association from 1956 to 1979 had been one of the principal drivers behind IAH during the first two decades of its life. Without his untiring work, thousands of letters, contacts and negotiations, and his unfailing presence at international meetings, the association would never have attained the enviable international reputation it began to enjoy during the late 1970s. Dubertret had been a pivotal figure in putting IAH on a sound footing, and his death brought to a close a crucial phase in the association's development. 


\section{The international growth years: 1979-2000}

\section{Rapidly growing membership}

The sudden death of Louis Dubertret hit the association and its Secretariat very hard. However, President Phil LaMoreaux found an enthusiastic and energetic successor as secretary general in the person of Erik Romijn from the Provincial Agency of Gelderland in The Netherlands. Romijn brought renewed vigour to the association at a time when, by good fortune, the global need for groundwater mapping and sound approaches to resource protection and sustainable aquifer management was rapidly accelerating. As a result, the association entered a period of very strong international growth (Fig. 2). In 1980, IAH had 1,032 members from 53 countries. By 1996, membership had increased to 3,523 individual and corporate members representing 118 countries. The broadening geographical spread was reflected in new European chapters including Norway, Switzerland, Poland and Romania and further afield in Argentina, Australia, Chile, Egypt, India, Korea, PR China, Mexico and South Africa.

Membership growth also promoted greater scientific activity with the creation of new commissions for 'remote sensing', 'hydrogeology of coastal areas', and 'hydrogeology of hazardous waste' (Table 2). During this period, groundwater quality issues and the need to protect aquifers from pollution from human activities became a major focus of IAH's scientific efforts. Intensive agriculture had been identified as a major source of groundwater pollution and a search was beginning for safe and secure underground storage repositories of hazardous radioactive waste from the nuclear industry. Hydrogeological attention turned on the one hand to shallow aquifers most vulnerable to land use change and, on the other, to non-aquifer formations of very low permeability.
The activity and productivity of a number of the commissions was further strengthened by the valuable support of UNESCO in aspects of hydrogeology which had close links to the themes and tasks of the IHP. At this time, these particularly focussed on karstic regions, on the contributions of the Commission on Hydrogeological Maps and on groundwater protection. The work of the commissions greatly contributed to scientific meetings on these subjects (Table 3); the IGC (held every 4 years) and the more regular IAH congresses and symposia also helped to establish the IAH "blue" book series (IAH International Contributions to Hydrogeology) and a little later the "green" book series (IAH Selected Papers).

\section{Establishing IAH's books and journal}

Egon Groba, IAH Treasurer from 1968-1989 (Table 1), must be given great credit for the association's publication initiatives during the early 1980s; however, good fortune also played a key role. Groba, it seems, was hospitalised when he happened to meet Christian Heise who was confined to a neighbouring hospital bed. Heise owned Heise Verlag (publishers), a major printing company in Hannover, Germany, that was seeking to expand into the publishing of science books. Both gentlemen seized upon this opportunity and entered an agreement that would serve both parties well for many years to come. IAH would prepare and deliver copyready manuscripts of the International Contributions to Hydrogeology and Heise would publish, print and distribute them free of charge to IAH members, while retaining the right to sell additional copies on the global market. In addition, Christian Heise generously agreed to print the Information Bulletins and Membership Directories at no cost to IAH.

The Selected Papers series was started by Andrew Skinner and Ian Simmers in 1990. This was a response to the decision
Fig. 2 IAH membership growth between 1956 and 2015

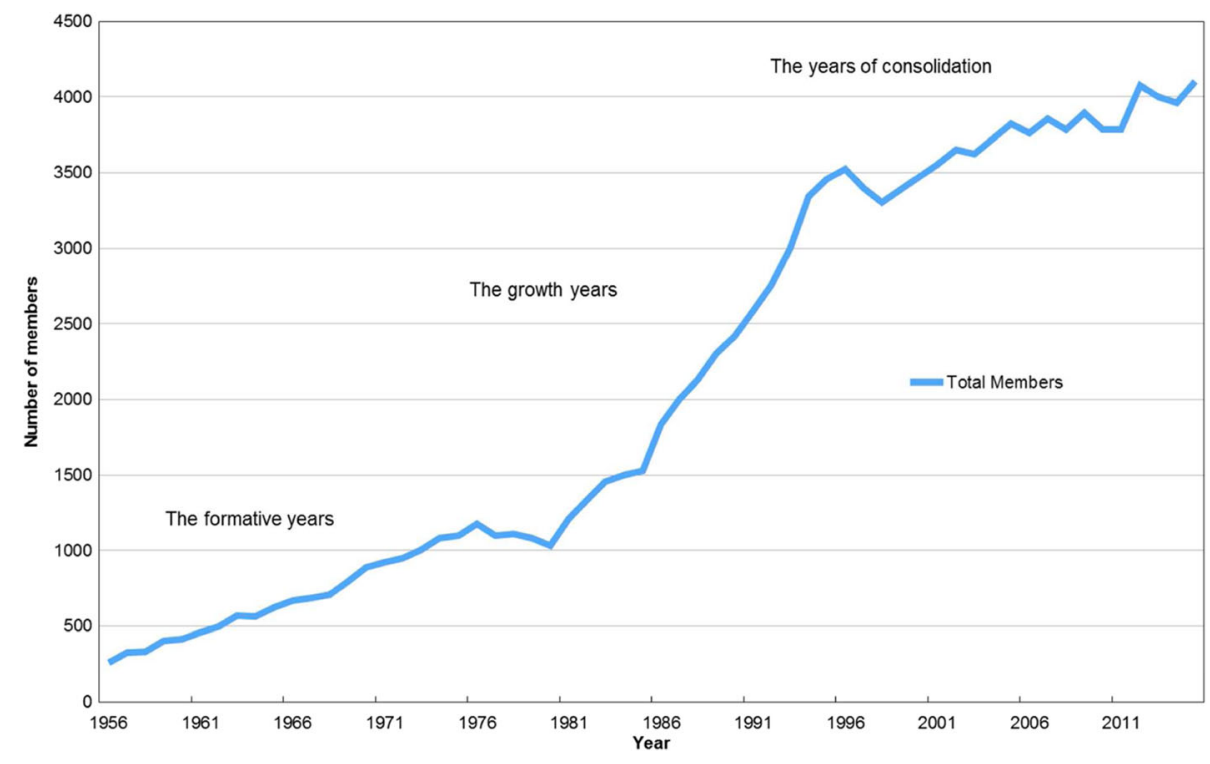


Table 4 IAH International Contributions to Hydrogeology ("blue" book series)

\begin{tabular}{|c|c|c|}
\hline Volume & Year & Theme \\
\hline 1 & 1984 & Hydrogeology of karst terrains: case histories ${ }^{\mathrm{a}, \mathrm{b}}$ \\
\hline 2 & 1986 & Hydrogeology of limestone terranes: annotated bibliography of carbonate rocks, volume $3^{\mathrm{a}, \mathrm{b}}$ \\
\hline 3 & 1984 & List of the terms of hydrogeology, geochemistry and mineral and thermal waters ${ }^{\mathrm{a}, \mathrm{b}}$ \\
\hline 4 & 1984 & Hydrogeology of the Dinaric Karst ${ }^{\mathrm{a}}$ \\
\hline 5 & 1986 & Impact of agricultural activities on groundwater ${ }^{\mathrm{a}, \mathrm{b}, \mathrm{c}}$ \\
\hline 6 & 1985 & Theoretical background, hydrogeology and practice of protection zones ${ }^{\mathrm{a}, \mathrm{b}}$ \\
\hline 7 & 1985 & $\begin{array}{l}\text { Hydrogeological mapping in Asia and the Pacific regions: proceedings of an } \\
\text { ESCAP workshop, Bandung, } 1983\end{array}$ \\
\hline 8 & 1990 & Groundwater recharge: a guide to understanding and estimating natural recharge $\mathrm{e}^{\mathrm{a}, \mathrm{b}}$ \\
\hline 9 & 1989 & Well logging in groundwater development ${ }^{\mathrm{b}}$ \\
\hline 10 & 1989 & Hydrogeology of limestone terrains: annotated bibliography of carbonate rocks, volume $4^{\mathrm{a}}$ \\
\hline 11 & 1991 & Hydrogeology of salt water intrusion: a selection of SWIM papers ${ }^{\mathrm{a}, \mathrm{c}}$ \\
\hline 12 & 1990 & Hydrogeology and management of hazardous waste for deep-well disposal ${ }^{\mathrm{a}, \mathrm{b}}$ \\
\hline 13 & 1992 & Hydrogeology of selected karst regions ${ }^{\mathrm{a}, \mathrm{d}}$ \\
\hline 14 & 1993 & Annotated bibliography of karst terranes, volume $5^{\mathrm{a}, \mathrm{b}}$ \\
\hline 15 & 1994 & Hydrogeothermics ${ }^{\mathrm{a}}$ \\
\hline 16 & 1994 & Guidebook on mapping groundwater vulnerability ${ }^{\mathrm{a}, \mathrm{b}}$ \\
\hline 17 & 1995 & Hydrogeological maps: a guide and standard legend $\mathrm{d}^{\mathrm{a}, \mathrm{b}}$ \\
\hline \multicolumn{3}{|c|}{ Balkema takes over Heise and continues publication of ICH series } \\
\hline 18 & 1998 & Shallow groundwater systems ${ }^{\mathrm{c}}$ \\
\hline 19 & 1998 & Recharge of phreatic aquifers in (semi-) arid areas ${ }^{\mathrm{b}}$ \\
\hline 20 & 1999 & Karst hydrogeology and human activities: impacts, consequences and implications ${ }^{\mathrm{a}}$ \\
\hline 21 & 1999 & Groundwater in the urban environment: selected city profiles ${ }^{\mathrm{c}}$ \\
\hline 22 & 2002 & Managing water well deterioration \\
\hline 23 & 2003 & Understanding water in a dry environment: hydrological processes in arid and semi-arid zones \\
\hline 24 & 2003 & Urban groundwater pollution ${ }^{\mathrm{a}, \mathrm{b}}$ \\
\hline 25 & 2005 & Introduction to isotope hydrology: stable isotopes of hydrogen, oxygen and carbon \\
\hline \multicolumn{3}{|c|}{ Taylor and Francis takes over Balkema and continues publication of ICH series } \\
\hline 26 & 2007 & Methods in karst hydrogeology ${ }^{\mathrm{a}}$ \\
\hline 27 & 2011 & Climate change effects on groundwater: a global synthesis of findings and recommendations $\mathrm{s}^{\mathrm{a}, \mathrm{b}}$ \\
\hline 28 & 2012 & History of hydrogeology \\
\hline
\end{tabular}

Notes:

${ }^{\text {a }}$ Output from the work of an IAH commission

${ }^{\mathrm{b}}$ Directly linked to projects within UNESCO IHP

${ }^{\mathrm{c}}$ Drawn from conference or congress proceedings

${ }^{\text {d }}$ Linked to IUGS-IGCP

Updates can be found on the IAH website (IAH 2016)

to discontinue the distribution of congress memoirs to all members and was designed to provide a means of publishing papers of merit which would otherwise be lost in congress proceedings of variable quality and accessibility in the predigital age. By 1996, when Balkema Publishers took over the two IAH book series from Heise, 17 volumes of the International Contributions to Hydrogeology (ICH) had been published (Table 4). The publisher Taylor \& Francis took over Balkema in the early 2000s and continues to publish the book series today.
Many of the IAH blue books enabled the work of the commissions to be published as contributions to the groundwater science topics of the time, for which the series was intended. The themes are listed in Table 4, indicating those which arose from the work of the IAH commissions and those which were directly linked to specific activities within IHP and/or supported by UNESCO. The titles show that, for the most part, during the 1980s and 1990s, investigating and describing the geological settings in which aquifers and groundwater resources could be found remained a dominant emphasis for IAH and its 
Fig. 3 Ian Simmers, Andrew Skinner, Eugene Simpson and Christian Heise at the Sherlock Holmes Hotel, London, in 1991 (photo courtesy of Andrew Skinner)

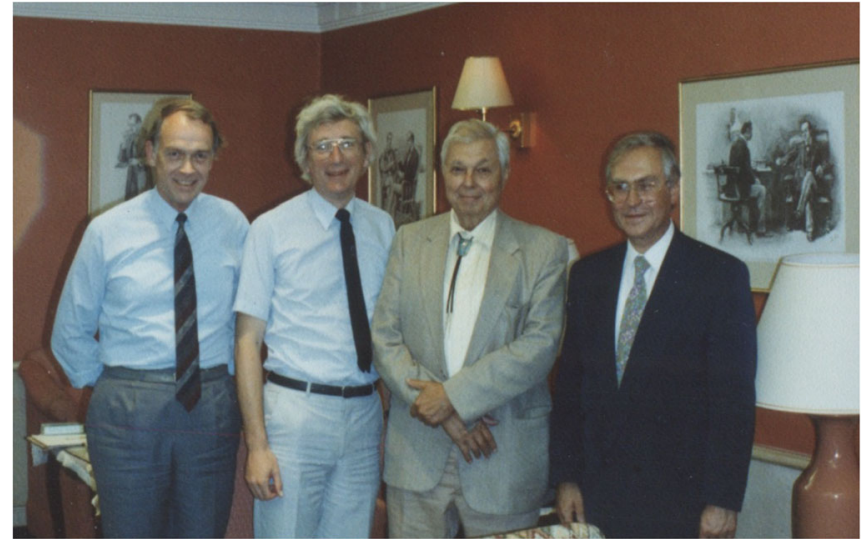

commissions. In particular, the joint scientific endeavours of IAH commissions and IHP working groups on karstic aquifer systems (volumes 1, 2, 4, Table 4), on groundwater vulnerability and protection (volumes 6 and 16), the international map legend (volume 17) and agricultural and urban impacts on groundwater systems (volumes 5 and 24) were well-recognised contributions in their respective fields of hydrogeology. Further details of all of these publications can be found on the IAH website along with information about how to obtain them.

It had long been an ambition of the association to produce its own scientific journal to complement the well-established book series, and approval to establish an IAH journal was given by Council at the Guilin congress in 1988. Heise was also behind the 1992 launch of the journal, Applied Hydrogeology, publishing it four times each year under the editorship of Eugene Simpson. The agreement to establish the journal was concluded in the summer of 1991 at the Sherlock Holmes Hotel in Baker Street, London, between Eugene Simpson, Christian Heise and IAH Secretary General Andrew Skinner (Fig. 3). In 1995, when Cliff Voss and Bill Wilson began as editors, the title was changed to Hydrogeology Journal. The title Hydrogeology was not available, to avoid any confusion with the existing journal Hydrogéologie published by BRGM in France. In 1997, Springer took over as publisher and the journal flourished, expanding to six issues per year from 1999. Over the years, Hydrogeology Journal has emerged to become one of the association's great success stories.

\section{Broadening the scope of IAH activities in the $1980 \mathrm{~s}$}

During this period, the familiar shield-design logo for IAH came into being (Fig. 4), reflecting the strongly geological origins of the association. This distinctive emblem was proposed by Jaroslav Vrba for the 1986 congress in Karlovy Vary and drawn by a Czech artist who normally worked on designs for postage stamps. Taking the explanation of the logo from a letter from Jaroslav Vrba to Erik Romijn in February 1985, the crosses in the lowermost part of the shield use the established geological notation for crystalline igneous rocks. The bands of blue and yellow across the centre of the shield represent sedimentary formations containing water and the uppermost solid part of the shield represents the soil and an impermeable confining layer. The blue symbol in the centre represents a drop of water moving through this sequence. Thus, the logo encapsulates the very essence of hydrogeology; understanding and depicting the subsurface, recognising aquifers and nonaquifers and the way in which groundwater derives from infiltration from the land surface. The logo was published for the first time at the top of the News and Information newsletter in May 1985 and widely used at the 1986 congress, for which the first logo lapel badges were produced. In 1989 "aih" was added to the logo. Using both "iah" and "aih" balanced the logo design and indicated the association's name in the principal IAH languages of the time. Subsequent IAH councils and members have wished to retain this strong link to those responsible for the founding and growth of IAH during its formative years. For the 60th anniversary, minor amendments have been made to improve the clarity of digital reproduction of the logo in a range

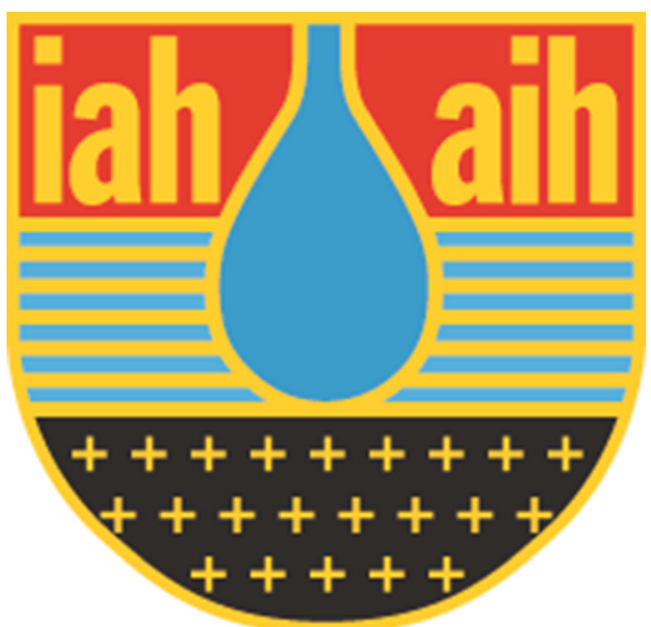

Fig. 4 Logo of the International Association of Hydrogeologists (IAH) 
of formats and a birthday sash superimposed for use during the year (Chilton and Howard 2016).

The principal focus of IAH's charitable activities, the Burdon Fund, came into being at this time. The fund was a legacy established in memory of David Burdon, a long-time member of the Irish national group and one of those present at the initiation of IAH in 1956. The associated Burdon Commission (now the Burdon Groundwater Network for International Development, Table 2) was set up in the mid 1980s specifically to support IAH members in lower income countries. At the initiative of Ramon Llamas and Erik Romijn, president and secretary general at the time (Table 1), a sponsored membership scheme was proposed by the Burdon Commission in 1987 and formalised and launched in 1989. This, one of the first such schemes established by a professional association, enabled individual members, national chapters and central funds to support colleagues who, for economic or administrative reasons were unable to pay for their own membership. There were 20 subscribers in the first year and numbers stayed fairly static until in 1993 when administration of the scheme was transferred to the IAH Secretariat.

The achievements of the association should not be measured only in numbers. Much of the success of IAH throughout its life has come from the personal commitment to the expanding community of groundwater colleagues shown by people who had given, and still give, hours of their time over many years. To recognise this, the Council of IAH established the award of Honorary Membership in 1982 and the Presidents' Award in 1995. The former is intended to reflect sustained commitments to the work of the association and the latter is given for a combination of contribution to the science of hydrogeology and to the work of IAH. The first awards (Fig. 5) recognised many of those who had contributed most substantially to the early years of the growth of IAH, and the full list can be seen on the IAH website (IAH 2016).

Erik Romijn's role as secretary general came to a close in 1989 when he was elected president (Table 1). At this time, IAH was evolving rapidly with membership doubling in a decade, many new national chapters being formed and a

Fig. 5 IAH President John Moore giving the 1996 Presidents' Award to Yuan Daoxian (photo courtesy of Andrew Skinner) blossoming array of publications and membership services. The stated aim of the association was to "further hydrogeological science by promoting cooperation between hydrogeologists of all nations and practitioners of other disciplines concerned with hydrogeological problems." This was to be achieved primarily by collaboration in research, publications and conferences with other scientific associations (Day 1992). This restates the original objectives but recognises the broadening global reach and expanding membership of IAH.

\section{Reviewing IAH's plans and strategies in the 1990s}

It was clearly time to pause for thought and plan more strategically. IAH's first meeting specifically for this purpose took place in Prague in May 1992 and it is worth recording that its genesis came partly from contemporary world events. The socalled Velvet Revolution had taken place in the then Czechoslovakia in 1989, following events in Poland and the former East Germany. The IAH Czechoslovak National Committee held funds in non-convertible Czechoslovak Crowns which were very likely to lose value with the financial changes taking place as the new Czechoslovak state was formed. Jaroslav Vrba therefore approached IAH Vice President John Day with a plan to utilise the funds in Prague by hosting the strategy meeting, and Day recommended this invitation should be accepted. The opportunity was timely in the light of the changing circumstances of IAH and with the need to react to the international priorities arising from the UN Water Conference in Dublin earlier that year. In all, 24 IAH members from the Council of IAH and its advisors, national committees and commissions were joined by representatives of sister societies, IAHS and the International Association of Engineering Geology (IAEG), and from UNESCO IHP, whose fifth phase was to start in 1995 and would be strongly influenced by the outcome of the Dublin conference.

The group met over 4 days to consider the outcome of the Dublin conference, to review the current organisation of IAH, to review the work of IAH in developing countries and to

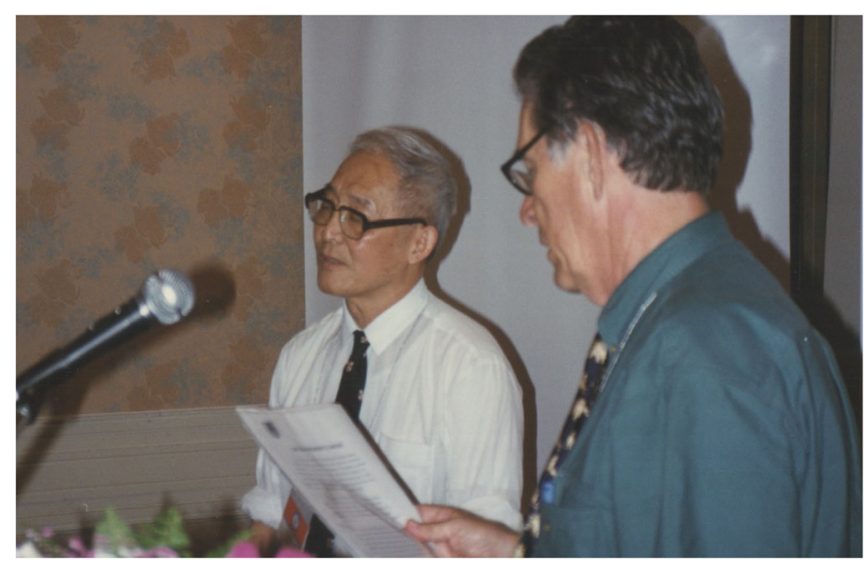


Table 5 Regional IAH membership, 2002-2015

\begin{tabular}{|c|c|c|c|c|c|c|c|c|c|c|c|c|c|c|}
\hline REGION & 2002 & 2003 & 2004 & 2005 & 2006 & 2007 & 2008 & 2009 & 2010 & 2011 & 2012 & 2013 & 2014 & 2015 \\
\hline Sub-Saharan Africa & 165 & 167 & 159 & 206 & 202 & 204 & 200 & 247 & 231 & 233 & 267 & 265 & 281 & 277 \\
\hline North Africa and the Middle East & 75 & 77 & 86 & 84 & 78 & 90 & 90 & 74 & 99 & 97 & 101 & 94 & 109 & 117 \\
\hline Asia & 243 & 218 & 218 & 238 & 265 & 263 & 288 & 214 & 191 & 191 & 229 & 259 & 300 & 316 \\
\hline Australasia and the Pacific & 389 & 426 & 455 & 502 & 477 & 496 & 493 & 599 & 582 & 656 & 799 & 697 & 589 & 708 \\
\hline Eastern Europe & 242 & 217 & 235 & 338 & 351 & 365 & 355 & 145 & 125 & 122 & 124 & 141 & 136 & 140 \\
\hline North America & 754 & 720 & 697 & 704 & 695 & 685 & 669 & 672 & 654 & 632 & 659 & 574 & 602 & 583 \\
\hline Latin America and the Caribbean & 309 & 300 & 300 & 213 & 211 & 207 & 194 & 177 & 177 & 197 & 179 & 182 & 197 & 229 \\
\hline Western Europe & 1,473 & 1,496 & 1,573 & 1,539 & 1,485 & 1,545 & 1,496 & 1,766 & 1,726 & 1,656 & 1,716 & 1,685 & 1,747 & 1,733 \\
\hline Total & 3,650 & 3,621 & 3,725 & 3,824 & 3,763 & 3,857 & 3,786 & 3,894 & 3,785 & 3,784 & 4,074 & 3,897 & 3,961 & 4,103 \\
\hline
\end{tabular}

draw up an action plan. The plan focused on the 5 years from 1992 to 1997 and addressed both the priority technical areas on which it was believed IAH should concentrate its resources and also the key organisational needs which the group identified. Much of the scientific and technical work of the association was to be covered by two principal themes: developing technical understanding in key topic areas in hydrogeology and increasing public understanding of groundwater issues. At the time the former were identified as:

1. Better management of groundwater resources in urban areas to prevent overuse and contamination from inadequately controlled land use practices

2. Sustainable management of groundwater resources in arid and semi-arid regions, either alone or in conjunction with surface waters; quantification of recharge and understanding of flow processes to help achieve this

3. Methods for protecting the quality and quantity of groundwater, including a methodology for monitoring, identification of the susceptibility to human impacts and integration with land-use planning

4. Methods of management to ensure sustainable use of groundwater in harmony with aquatic ecosystems that depend upon groundwater; improved understanding of the sensitivity of ecosystems to changes in the quality and availability of groundwater

The plan was accepted by Council at its meeting in September 1992. Efforts were subsequently made in the period up to the new millennium to encourage new commissions to take up some of these challenges (Table 2), and the book themes in Table 3 also reflect this evolving emphasis.

Organising the Prague meeting was one of the first major responsibilities for Andrew Skinner, the incoming secretary general who had inherited this role from Erik Romijn in 1989. At the meeting, the fragmented nature of the IAH administration and consequent inefficiencies were discussed.
The new secretary general presented a plan to Council in Karlsruhe in September 1992 and the Secretariat settled in the United Kingdom in 1993. The association needed a careful hand on the tiller during these demanding but exciting times, and Skinner fitted that bill perfectly. A small team of part-time administrative assistants was appointed and he set about turning IAH into a modern, efficient, professional organisation with a management structure and governance appropriate for a membership that was fast approaching 4,000 (Fig. 2). Working closely with Council led by Michael Knight of Australia, President from 1996 to 2000 (Table 1), Skinner was able to ensure that IAH began the new millennium as a fully incorporated limited company and registered charity with a rigorous set of association rules and articles. Thus, from the 12th Council of IAH (Table 1), council members also became directors of the company and trustees of the charity. After 10 years of unprecedented growth, incorporation provided IAH with a sound foundation on which to build a sustainable future and Emilio Custodio, the first IAH president after incorporation (Table 1) was responsible for setting the association off on its new path. He firmly supported the use of English as the primary working language for IAH but also helped to make the outputs of the association available in Spanish and Portuguese. IAH owes much of its strength in Iberia and Latin America to his status and influence and he continues to support members and chapters during his travels to Latin America.

\section{Consolidation and adapting to change: 2000-2016}

\section{Membership broadens rather than grows}

This most recent period of IAH's history has been one of consolidation rather than expansion of membership, of responding to evolving scientific directions in hydrogeology and of adapting the management, administration and means of communication of the association to contemporary needs. The 
membership of IAH reached 3,750 in 1995 (Fig. 2) and has increased only gradually since then, passing 4,000 in 2012 and again in 2015. During this time, IAH has gained and lost 300-400 members each year, with the precise annual balance between these determining whether a small overall increase or decrease is seen (Fig. 2). The association now has members in 131 countries, and the number of chapters has grown to over 40 including new chapters in Denmark, Hungary, Morocco and Portugal and most recently in Sweden, New Zealand, Iraq and Turkey. Regional membership trends are shown in Table 5. While some regions have shown steady growth over this period, others have seen fluctuations which often reflect regional economic ups and downs. The sharp jump in members in Western Europe and equivalent decline in Eastern Europe in 2009 resulted from a transfer of national chapters and members with the accession of new countries to the European Union and its consequent expansion eastwards.

The character and composition of the association has continued to broaden, with successive presidents and councils encouraging membership from outside what might be termed classical academic hydrogeology. Many new members were drawn from public sector regulatory agencies and the private sector as well as the more traditional sources in universities and geological surveys and are working in groundwater investigation, protection and management from a much wider range of disciplines. The broadening professional range and greater geographical reach has certainly strengthened IAH's ability to live up to its title and to speak with greater authority for groundwater globally. This was reflected in adoption by IAH of the strapline "Worldwide Groundwater Organisation" in 2005. Moreover, some of the established IAH chapters such as those in Australia and Ireland have been particularly effective in capturing a broader range of disciplines, enabling them to have a much more effective groundwater voice at a national level.

\section{The books and journal flourish}

Hydrogeology Journal has continued to flourish under the steady hand of Executive Editor Cliff Voss and his team. The number of manuscripts submitted has grown steadily to more than 400 per year, producing a significantly increasing editorial workload and the journal team was augmented by two part-time editorial office staff, one from 2001 and one more from 2005, and four managing editors from 2005. The published journal increased to eight issues per year from 2006 and now contains about 130 published articles and 1,800 to 1,900 pages annually. The team prides itself on the broad geographical spread of content and authors which is nevertheless balanced by a steady increase in impact factor to 1.97 in 2014 (Springer 2016). The theme issues of the journal reflect very well the evolving focus of groundwater research during this period (Table 6), and the fact that theme issue papers are amongst the most cited in the journal is an indication of their contribution to current hydrogeological science. The journal has also needed to respond to the broader evolving environment of scientific publication and the changing requirements of IAH members by introducing on-line access to the journal in 2007 and an open access option for authors from 2014. The journal will celebrate its 25th anniversary in 2017 in several ways, including publication of a full historical article in this journal.

Publication of the two IAH book series has continued, firstly under the guidance of Ian Simmers and, since 2006, of Nick Robins. Finding authors willing and able to commit the substantial time required to write or edit an ICH "blue book" has become much more difficult and the series has faltered somewhat in recent years (Table 3). This is a broad issue affecting book publication by many professional associations; academic priority is to devote the time to papers for publication in cited journals. The Selected Papers green book series continues to provide participants at IAH congresses and other conferences with opportunities for topic-based groups of papers developed from their presentations to be published (Table 7). Further details of these publications can be found in the 'Publications' section of the IAH website (IAH 2016) with information about how to obtain them.

Congresses have continued to provide an important focus for the association's activities. Congress themes over the past 60 years (Tables 3 and 7) reflect the evolution of the science of

Table 6 Hydrogeology Journal theme issues

\begin{tabular}{ll}
\hline Year & Theme title \\
\hline 1996 & Urban groundwater \\
1997 & Groundwater processes in land and water salinisation \\
1998 & Tribute to Eugene S. Simpson \\
1999 & Groundwater as a geologic agent \\
2000 & Groundwater and microbial processes \\
2001 & Confining units \\
2002 & Groundwater recharge \\
2003 & Hydromechanics in geology and geotechnics \\
2004 & Groundwater: from development to management \\
2005 & The future of hydrogeology \\
2006 & Social and economic aspects of groundwater governance \\
2007 & Remote sensing and GIS in hydrogeology \\
2009 & Hydrogeoecology and groundwater dependent ecosystems \\
2010 & Saltwater and freshwater interactions in coastal aquifers \\
2011 & Insights from environmental tracers in groundwater systems \\
2012 & Economics of groundwater management \\
2013 & Hydrogeology of cold regions \\
2014 & Hydrogeology of shallow thermal systems \\
2015 & Optimization for groundwater characterization and management \\
2016 & Land subsidence processes \\
\hline &
\end{tabular}

Updates can be found on the IAH website (IAH 2016) 
hydrogeology into new areas and the increasing importance of protecting and managing groundwater in response to growing quantity and quality pressures on aquifers. They also reflect the growing appreciation of the economic and social dimensions of groundwater and the need to use hydrogeological knowledge, skills and tools as a basis for improved management of groundwater resources. Beijing in 1996 was the last time IAH gave precedence to the four yearly IGC cycle in arranging its congresses; and, from the 27th in Nottingham (UK) in 1997 to the 42nd in Rome in 2015 (Fig. 6), congresses have been held almost every year. As well as the opportunity for both IAH members and non-members to present the findings of their own research in the technical sessions, they have also provided an essential opportunity for the IAH commissions and networks to describe their current and planned activities and attract new participants. Many productive research partnerships have originated from discussions at congresses. Local organising committees, supported by the IAH Executive and Secretariat, have improved the professionalism of the congresses, strengthening the scientific quality but at the same time striving to keep costs as affordable as possible. This has seen attendances regularly top 600 and reach almost 1000 in Niagara Falls, Canada, in 2012. Although sadly increasing time pressures on working people and financial constraints have combined to lessen the part that the traditional post-congress field trips have played, overall the congresses still provide a vital part in the life of the association and the best opportunity for the global IAH "family" to meet.

\section{Further strategic review}

Incorporation provided a sound governance and administrative basis for the association to move into the new

Table 7 IAH Selected Papers ("green” book series)

\begin{tabular}{|c|c|c|}
\hline Volume & Year & Theme \\
\hline 1 & 1990 & Selected papers on hydrogeology from the 28th IGC, Washington, DC, 1989 \\
\hline 2 & 1993 & Hydrogeology of hard rocks, selected papers originating from the 24th IAH Congress, Oslo, 1993 \\
\hline 3 & 1992 & Selected papers on aquifer overexploitation from the 23rd IAH Congress, Tenerife, 1991 \\
\hline 4 & 1993 & Selected papers on environmental hydrogeology from the 29th IGC, Kyoto, 1992 \\
\hline \multicolumn{3}{|c|}{ Balkema takes over Heise and then becomes part of Taylor and Francis with an interruption to the series } \\
\hline 5 & 2005 & Nitrates in groundwater; papers from a Euromeet at Wisła, Poland in $2002^{\mathrm{a}}$ \\
\hline 6 & 2005 & $\begin{array}{l}\text { Groundwater and human development, selected papers from the 32nd IAH Congress, } \\
\text { Mar del Plata, Argentina } 2002\end{array}$ \\
\hline 7 & 2005 & Groundwater intensive use, selected papers from SINEX, Valencia, $2002^{\mathrm{a}}$ \\
\hline 8 & 2007 & Urban groundwater: meeting the challenge, selected papers from the 32nd IGC, Florence, $2004^{\mathrm{a}, \mathrm{b}}$ \\
\hline 9 & 2007 & Groundwater in fractured rocks, selected papers from the conference in Prague, $2003^{\mathrm{a}}$ \\
\hline 10 & 2007 & Aquifer systems management, selected papers from the IAH Symposium, Dijon, 2006 \\
\hline 11 & 2007 & Groundwater vulnerability assessment and mapping, selected papers from the conference in Ustroń, Poland, 2004 \\
\hline 12 & 2008 & $\begin{array}{l}\text { Groundwater flow understanding: from local to regional scale, selected papers from the 33rd IAH } \\
\text { Congress, Zacatecas, Mexico, } 2004\end{array}$ \\
\hline 13 & 2008 & Applied groundwater studies in Africa ${ }^{\mathrm{b}}$ \\
\hline 14 & 2008 & $\begin{array}{l}\text { Advances in subsurface pollution of porous media: indicators, processes and modelling; selected } \\
\text { papers from the EU COST-629 Final Conference, Barcelona, } 2007\end{array}$ \\
\hline 15 & 2009 & Groundwater governance in the Indo-Gangetic and Yellow River basins: realities and challenges \\
\hline 16 & 2010 & Groundwater response to changing climate, selected papers from the 36 th IAH Congress, Toyama, Japan, $2008^{\mathrm{a}, \mathrm{b}}$ \\
\hline 17 & 2013 & Groundwater quality sustainability: selected papers from the 38th IAH Congress, Krakow, Poland, 2010 \\
\hline 18 & 2013 & Groundwater and ecosystems: selected papers from the 35th IAH Congress, Lisbon, 2007 \\
\hline 19 & 2013 & $\begin{array}{l}\text { Assessing and managing groundwater in different environments: selected papers from the } \\
\text { Groundwater Division of the Geological Society of South Africa conference, Pretoria, } 2011\end{array}$ \\
\hline 20 & 2014 & Fractured rock hydrogeology: selected papers from the Fractured Rock Conference in Prague, $2012^{\mathrm{a}}$ \\
\hline 21 & 2014 & Calcium and magnesium in groundwater \\
\hline 22 & 2016 & $\begin{array}{l}\text { Solving the groundwater challenges of the } 21 \text { st century: selected papers from the } 40 \text { th IAH } \\
\text { Congress, Perth, Australia, } 2013\end{array}$ \\
\hline 23 & 2016 & Karst without boundaries: selected papers from the Karst Conference at Trebinje, Bosnia and Herzegovina, 2014 \\
\hline
\end{tabular}

${ }^{\text {a }}$ Directly linked to UNESCO IHP projects

${ }^{\mathrm{b}}$ Outputs from the work of an IAH commission

Updates can be found on the IAH website (IAH 2016) 


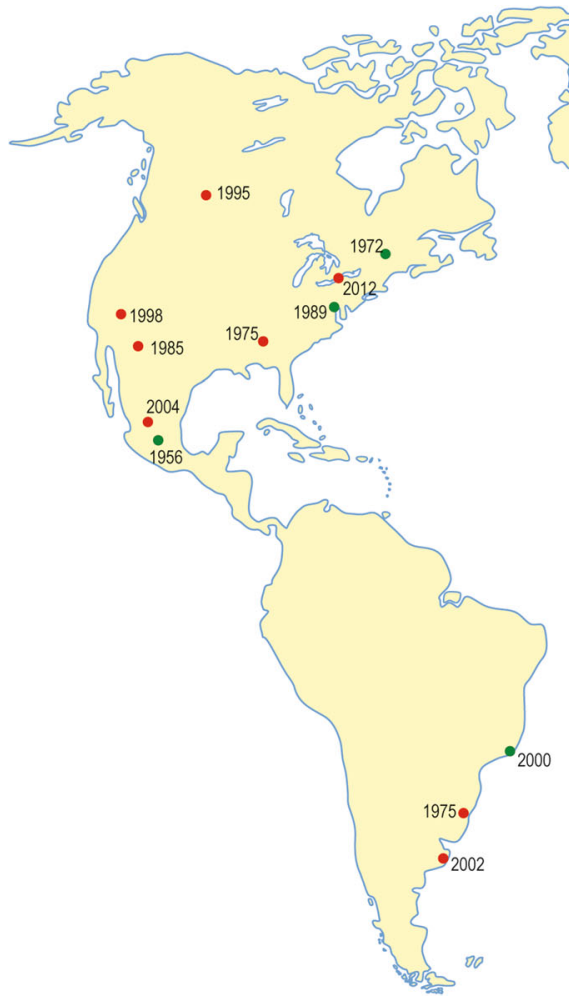

Fig. 6 Locations of IAH congresses

millennium but, as already mentioned, responding to rapid change needs opportunities to think strategically. A second IAH strategic meeting was held at Stana de Vale, Romania, in May 2002 at the invitation of Florian Zamfirescu and the Romanian National Chapter (Fig. 7). In all, 35 participants from 19 countries, again representing the Council of IAH, commissions and national chapters, discussed and set out some new strategic priorities for the association. The four days of meetings, presentations and field excursions provided an opportunity for in depth discussions on the challenges and priorities for IAH over the next decade. The meeting agreed the following topics should be among the priority actions for IAH over the following 5-10 years:
1. Collaboration with UNESCO in the 6th phase of the International Hydrological Programme (IHP)

2. Partnership with UN agencies to promote better understanding of the role of groundwater and to raise its profile in international water policy initiatives

3. Continue and develop special IAH initiatives in transboundary aquifer management; urban groundwater, groundwater and poverty alleviation; improved understanding and better characterisation of groundwater systems; understanding groundwater dependent ecosystems; groundwater and coastal zone management

4. Review the priorities and work of the Burdon Commission (now Network) and the use of the Burdon Fund
Fig. 7 Iancu Oreseanu (Romania), Jaroslav Vrba (Czech Republic), John Mather (UK), Florian Zamfirescu (Romania) and Michael Galabov (Bulgaria), in Romania in 2002 (photo courtesy of Andrew Skinner)

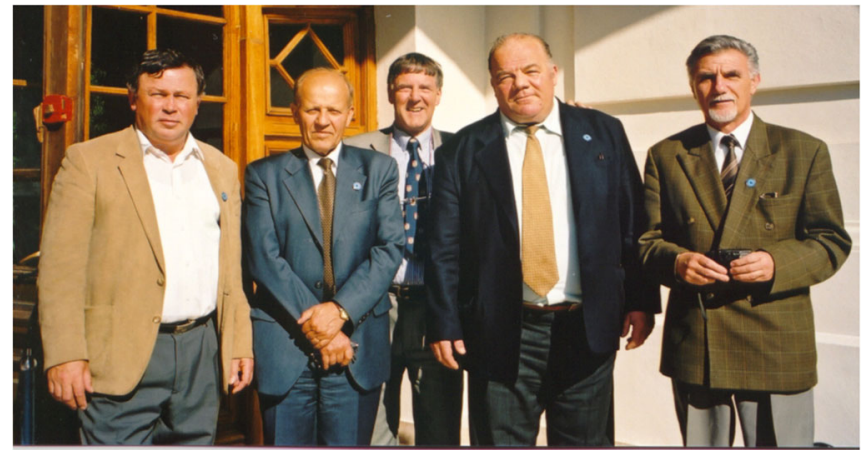


5. Develop income sources to supplement membership income through corporate sponsorship

6. Review the format and scheduling of congresses and the work of commissions and working groups in line with the objectives and priorities of the association

Again the areas of groundwater science, management and development listed in the preceding as No. 3 featured in the establishment of new commissions (Table 2) and in the work of existing commissions and in the publications (book series and Hydrogeology Journal). The IAH commissions have remained the focus of much of IAH's scientific activity. The evolution of scientific directions within hydrogeology has continued in the new millennium and the increasing importance of taking account of global change in managing groundwater resources and protecting aquifers from pollution was reflected in new commissions on 'groundwater and climate change' and on 'transboundary aquifers' (Table 2). The activities of many of the commissions and networks have benefited from IAH's close and long-term cooperation with UNESCO's IHP, as can be seen from the notes to the book lists in Tables 4 and 7 .

Recognising that the recommendations of the previous strategic meetings had not been fully implemented, the 14th Council of IAH (Table 1) agreed at its first meeting on the need for a comprehensive review of the association's activities. The process was initiated by a discussion in Council in Hyderabad, India, in September 2009, followed by consultation with national chapters and by a member survey. In July 2010, a 3-day meeting was convened in Reading, UK, attended by 24 participants representing Council, chapters, commissions and the broader membership. Under the guidance of Secretary General Shammy Puri, strategic priorities for IAH up to 2020 were set out under five main headings: the internal development of IAH, education and professional development, informing and influencing global policy, enhancement of alliances and partnerships, and developing the science of hydrogeology (IAH 2010).

\section{Adapting to evolving hydrogeological focus}

An important recommendation of the Forward Look was to complete the reform of IAH's commissions and networks, a process that had been initiated on behalf of Council by Vice President for Programme and Science Coordination Ken Howard in 2008 and was inherited by António Chambel following the 2012 IAH Council elections. Some of IAH's commissions had been too dependent on the energy and efforts of individuals and in some cases the initial enthusiasm had not been maintained or passed on to others (Table 2). The objectives of this review were to enable the association to close commissions which had become inactive or whose themes were now less topical, to establish new commissions in new topic areas and to encourage wider participation of younger professionals in their activities. As a result of the reform, some of the established commissions and networks have been closed and some rejuvenated and continue to prosper (Table 2). New commissions on 'regional groundwater flow' and on 'groundwater and energy' have added to the breadth of IAH's scientific endeavours.

Commissions which have contributed strongly to the science of hydrogeology through their meetings and publications include the Mineral and Thermal Waters Commission (Balderer et al. 2014), Managed Aquifer Recharge Commission chaired by Peter Dillon with its series of ISMAR conferences (International Symposium on Management of Aquifer Recharge), and the Karst Commission chaired by Nico Goldscheider with its meetings and publications. As an example of the latter, selected papers presented at the karst symposium in Malaga, Spain, in 2010 were published in a special issue of the journal Carbonates and Evaporites (March 2011, Issue 1). Commission outputs are also published both in Hydrogeology Journal (for example, Ghasemizadeh et al. 2012; Goldscheider et al. 2010) and as books (Kresic 2013).

The changing emphasis has also become embedded in the association's present mission, developed from the IAH Forward Look, to "further the understanding, wise use and protection of groundwater resources throughout the world". This evolution in emphasis is seen in the growing need for a responsible professional association to advocate for better awareness of groundwater amongst policy makers, the general public and professionals in other disciplines. This is achieved in several ways. One is through IAH's participation in the major global fora for water, such as the World Water Council (WWC) and the Global Water Partnership (GWP) and the events which these organisations convene such as the regular World Water Forum (Fig. 8) and Stockholm Water Week. IAH has built on its long-established links with UNESCO to become a partner in UN-Water, the umbrella grouping of all UN agencies which have an interest in water.

\section{Adapting activities to the new millennium}

One of the most successful innovations of recent years has been the establishment of an IAH Early Career Hydrogeologists ' Network (ECHN). This arose initially from seeing a similar endeavour by IAHS at the joint IAHS/IAH symposium in Hyderabad in 2009 and the idea was developed further in the discussions at the Forward Look meeting in 2010. What started as an informal group at the Krakow Congress in Poland in 2010 quickly became a formal IAH network within the revised structure established in 2011 (Table 2). The ECHN grew rapidly under the guidance of its first director Judith Flugge and has continued to prosper, convening technical sessions and organising lunchtime meetings and evening social events at each IAH congress. This has 
Fig. 8 Public discussion during an IAH/UNESCO session at the 2003 Kyoto World Water Forum, Japan (photo courtesy of Andrew Skinner)

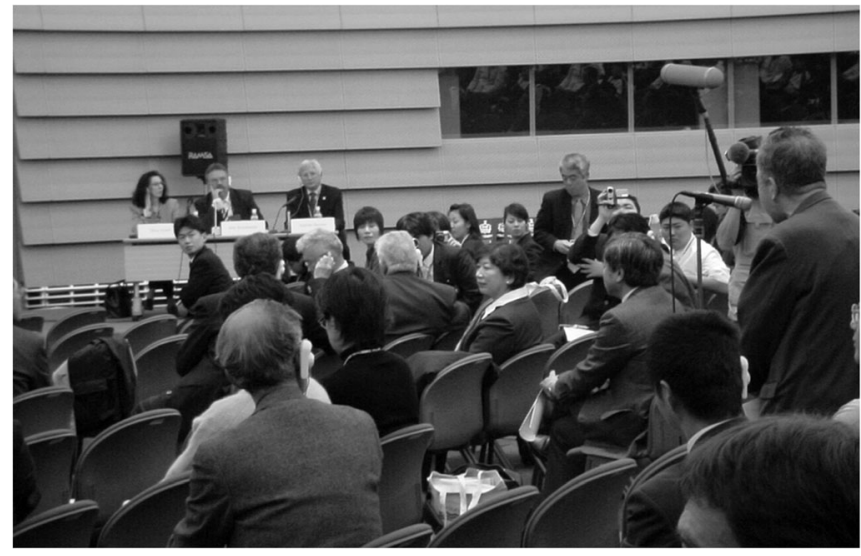

principal vehicle of IAH's charitable activities had been the Burdon Fund, and associated Burdon Commission (now the Burdon Groundwater Network for International Development). The Network supports IAH members in lower income countries, helping colleagues who sometimes feel rather isolated to become better informed and more confident in their work, encouraging professional contact and collaboration between countries and helping to stimulate the formation of new national chapters. IAH employs the Burdon Fund to provide regular free book distributions to members in Africa and to support attendance at IAH congresses. More recently, a Memorandum of Understanding has been established with the African Groundwater Network and funds used to provide partial support to some of their workshops on groundwater in integrated water resources management in African river basins. With the resources for more effective promotion, the sponsored members' scheme has grown much faster and now supports 265 colleagues.

The Hydrogeologists' Time Capsule, the inspiration of Craig Simmons and Philippe Renard, which they turned into a successful project in 2006, provides a substantial collection of video interviews of eminent hydrogeologists who have made a material difference to the profession (Simmons and Renard 2008). The recordings provide opportunities to understand personal motivations, aspirations and philosophies by hearing directly their own reflections on their work and its impact and their thoughts for the future. These recordings constitute an historical record for future generations, and many are augmented by profiles published in this journal (Bredehoeft 2008; Duncan and Voss 2013; Voss and Duncan 2013).

To be effective, advocacy and awareness-raising of course needs technically sound but appropriately written material. Examples of this include the brochure prepared for IAH's 50th anniversary in 2006 and policy briefs prepared jointly with UNESCO for the World Water Forum in Kyoto in 2003, both under the guidance of Stephen Foster. More recently, recognising the essential interconnections between groundwater and other sectors, to provide technical material to support the new Sustainable Development Goals and to mark the 60th 
anniversary, Stephen Foster has led the production of the IAH Strategic Overview Series, which is available on the Knowledge (Learning Resources) section of the IAH website (IAH 2016).

This changing emphasis is reflected in IAH's international partnerships. One of the most productive was that between the IAH Commission for Transboundary Aquifer Management (TARM) and UNESCO's Internationally Shared (transboundary) Aquifer Resources Management (ISARM) Programme (Puri and Aureli 2005). The TARM Commission's hydrogeological knowledge underpinned the work of the UN International Law Commission (ILC), such that a set of draft articles for a law on transboundary aquifers has been accepted by the UN General Assembly and now awaits ratification by countries. IAH colleagues from chapters including the Czech Republic, Denmark, France, Ireland, Italy, Spain and the UK, played a prominent role in supporting the European Commission in preparing the Water Framework Directive and Groundwater Directive and the associated guidance documents, and subsequently implementing their groundwater management and protection provisions at national level.

Since 2012, IAH has been a partner with FAO, UNESCO and the World Bank in a Global Environment Facility (GEF) project on groundwater governance. The present status of the governance and management of groundwater was examined by a series of country case studies and thematic papers and five regional consultations. IAH members contributed (partly through the IAH commissions) to the preparation of the case studies and the writing of four of the twelve thematic papers and provided their experience at the regional consultations. IAH provided most of the drafting team for the main outputs of the project, a global diagnostic of the present state of groundwater governance, the vision for improved governance, and a framework for action by which steps can be taken to reach this vision (FAO 2015a, b; Foster and van der Gun 2016).

\section{The future}

Over the past 60 years IAH has developed into a strong international groundwater association with a broad membership base, a well-regarded journal, established books series and a full programme of scientific meetings and well-attended congresses. Great credit for this success goes to members past and present who have dedicated untold hours to further the association's aims and objectives, not only centrally within the IAH Council and the IAH Secretariat, but regionally within its national chapters, commissions and networks. Today, IAH plays an important role advocating for groundwater in the global water agenda and pursuing its mission to further the understanding, wise use and protection of groundwater resources throughout the world.

Demanding at times, it has been a successful journey, but the 60th anniversary year represents only a milestone on a path that continues. Signs for the future are very positive but much work remains to be done to ensure IAH remains at the forefront, adapting both to the needs of its members and to those of society as a whole. The world is changing rapidly with population growth, pollution and a warming planet posing serious threats to the sustainability of water resources and water-dependent ecosystems. At its most recent meeting, IAH Council approved the birth of the Commission on Groundwater and Energy and these types of initiatives must continue. It is essential that the association's complement of commissions and networks remains responsive to the world's changing priorities and issues, contributing to the evolving science but also helping to meet related social and educational needs.

When Stevenson Buchan remarked back in 1972 that IAH was "reaching its maturity", he could hardly have foreseen the remarkable transformation IAH would undergo in the following 40 years. By the same reasoning, it is impossible for the current guardians of IAH to foretell what the next 40 years will bring. The association must strive to develop benefits which attract into membership the younger professionals whose active participation in all of IAH's activities is essential for the continuing health and strength of the association. Certainly there will be challenges, including the difficulty of providing attractive member services on a limited budget, which has been a recurring concern throughout the life of the association. Dedication, commitment and hard work will also be required. However, the association has gained good momentum over the past 60 years, morale is strong and optimism holds no bounds, especially given the injection of energy provided in recent years by the early career hydrogeologists in the ECHN, many of whom have taken on some important responsibilities within the IAH. These will be the new champions of IAH, and the future lies in their hands.

Acknowledgements The authors are especially grateful to Jean Margat and Jaroslav Vrba who gave up their time to meet Willi Struckmeier during 2015 to provide their recollections about the early years of the association. We thank Carla Skinner, Nick Robins, Cliff Voss and Sharon Warden for providing information and corrections and clarifications while the manuscript and tables were being prepared, and Stephen Foster for peer review comments on an earlier version of the article. We would also like to thank Gill Tyson for updating the congress location map (used at the time of IAH's 50th anniversary) and Sue Duncan for her advice during the final stages of preparing the article. The authors would also like to thank the three reviewers whose corrections and helpful suggestions have certainly improved this article.

\section{References}

Balderer W, Porowski A, Idris H, LaMoreaux JW (eds) (2014) Thermal and mineral waters: origins, properties and applications. Springer, Berlin

Bredehoeft JD (2008) An interview with C. V. Theis. Hydrogeol J 16:5-9 Chilton PJ, Howard KFW (2016) Editors' Message: IAH at sixty. Hydrogeol J 24:1-3 
Day JBW (1992) A brief account of the International Association of Hydrogeologists. Appl Hydrogeol J 0:47-50

Duncan SM, Voss CI (2013) Editors' Message: Eminent hydrogeologists profiled in 20 years of Hydrogeology Journal (1992-2012). Hydrogeol J 21:1385-1388

FAO (2015a) Global diagnostic on groundwater governance (Special edn. for World Water Forum 7). Groundwater Governance: A Global Framework for Action, GEF Groundwater Governance Project. http://www.groundwatergovernance.org. Accessed March 2016

FAO (2015b) Global framework for action to achieve the vision on groundwater governance (Special edn. for World Water Forum 7). GEF Groundwater Governance Project. http://www. groundwatergovernance.org/. Accessed March 2016

Foster SSD, van der Gun J (2016) Groundwater governance: key challenges in applying the global framework for action. Hydrogeol J. doi:10.1007/s10040-016-1376-0

Ghasemizadeh R, Hellweger F, Butscher C, Padilla I, Vesper D, Field M, Alshawabkeh A (2012) Review: Groundwater flow and transport modeling of karst aquifers, with particular reference to the North Coast Limestone aquifer system of Puerto Rico. Hydrogeol J 20: 1441-1461

Gilbrich WH, Struckmeier WF, (2014) 50 years of hydro(geo)logical mapping activities under the auspices of UNESCO, CGWM, IAH and BGR. http://unesdoc.unesco.org/images/0023/002310/ 231066e.pdf. Accessed March 2016

Goldscheider N, Mádl-Szőnyi J, Erőss A, Schill E (2010) Review: Thermal water resources in carbonate rock aquifers. Hydrogeol $\mathrm{J}$ 18:1303-1318
Gray DA, Mather JD (2004) Stevenson Buchan (1907-1996): field geologist, hydrogeologist and administrator. In: Mather JD (ed) 200 years of British hydrogeology. Geol Soc Lond Spec Publ 225: 287-293

IAH (2010) A forward look for our Association: IAH's future plans to 2020 and beyond. International Association of Hydrogeologists. https://iah.org/wp-content/uploads/2013/05/forwardlookweb.pdf. Accessed March 2016

IAH (2016) International Association of Hydrogeologists. https://iah. org/. Accessed March 2016

Kresic N (2013) Water in Karst: management, vulnerability, and restoration. McGraw-Hill, New York, 708 pp

Puri S, Aureli A (2005) Transboundary aquifers: a global programme to assess, evaluate and develop policy. Ground Water 43:661-668

Simmons CT, Renard P (2008) Editors' Message: the hydrogeologist time capsule - archival video recordings of influential hydrogeologists. Hydrogeol J 16:1-3

Springer (2016) Hydrogeology Journal. http://www.springer.com/earth+ sciences + and + geography/hydrogeology/journal/10040. Accessed March 2016

Struckmeier WF, Margat J (1995) Hydrogeological maps: a guide and a standard legend. International Contributions to Hydrogeology vol 17, Heise, Hannover, Germany

Voss CI, Duncan SM (2013) Erratum; Editors' Message: Online republication of legacy articles on the occasion of Hydrogeology Journal's 20th anniversary, 1992-2012, and Editors' Message: Eminent hydrogeologists profiled in 20 years of Hydrogeology Journal (1992-2012). Hydrogeol J 21:1683-1685 